\title{
Motivasi Siswa Dalam Mempelajari Bahasa Inggris Pada Ma Attarbiyah Addiniyah Gersik Kediri Lombok Barat
}

Alfan Hadi

Program Studi Pendidikan Agama Islam, STAI Al-Amin Gersik, Mataram, Indonesia, alvanshine@ymail.com

\begin{abstract}
Abstrak: Bahasa Inggris adalah salah satu mata pelajaran wajib yang harus ada dan dipelajari oleh siswa-siswa disekolah baik dari Sekolah Dasar sampai dengan Sekolah Menengah Umum. Adapun salah satu faktor yang bisa mempengaruhi keberhasilan dalam pembelajaran yaitu faktor motivasi siswa khususnya motivasi instrisik dan motivasi ekstrinsik. Dalam hal ini, peneliti mencoba untuk menemukan apakah motivasi memiliki hubungan dengan keberhasilan belajar siswa dalam mata pelajaran Bahasa Inggris atau mungkin sebaliknya. Berdasarkan hasil penelitian, maka bisa disimpulkan bahawa siswa MA Attarbiyah Addiniyah Gersik Kediri Lombok Barat cenderung memiliki motivasi tinggi yang datang dari ekstrinsik dibandingkan dari intrinsik dalam mempelajari Bahasa Inggris.
\end{abstract}

Kata Kunci: Motivasi Dan Bahasa Inggris

\begin{abstract}
English is one of the compulsory subjects that must exist and must be studied by students in schools from elementary school to senior high school. As for one of the factors that can affect success in learning, namely student motivation factors, especially intrinsic motivation and extrinsic motivation. In this case, the researcher tried to find out whether motivation has a relationship with students' learning success in English subjects. Based on the results of the study, it can be concluded that the students of MA Attarbiyah Addiniyah Gersik Kediri, West Lombok, who tend to have a high motivation that comes from extrinsic compared to intrinsic in learning English.
\end{abstract}

Key Word: Motivation and English

\section{PENDAHULUAN}

The primary motive for learning a langauge is that provides a means of communication (Littlewood, 2005). ${ }^{1}$ Menurutnya hal mendasar dalam mempelajari bahasa adalah untuk mengadakan sebuah alat untuk berkomunikasi. Bahasa sebagai alat yang digunakan oleh manusia untuk berkomunikasi dengan manusia lainnya dan bertujuan agar manusia saling memahami tentang apa yang mereka bicarakan dan inginkan (Kristin, L, Leah, D, M, and Tenena, M, S. 2010). ${ }^{2}$

Salah satu jenis Bahasa yang sangat perlu dipelajari adalah Bahasa Inggris, bahasa ini merupakan bahasa asing dan merupakan bahasa yang paling banyak

1 Littlewood, William T, Foreign and Second Language Learning, (Newyork: Cambridge University Press, 2005) h. 12

2 Kristin, L, Leah, D, M, and Tenena, M, S.. Teaching Reading to English Language Learners. (New York: The Guilford Press, 2010) h. 56 
digunakan dalam berkomunikasi secara internasional. Hal ini menajadi alasan mengapa bahasa inggris ini harus dipelajari dan dikuasai oleh siswa di sekolah menengah atas (SMA) atau yang sederajat.

Dalam mempelajari Bahasa Inggris, usaha yang maksimal sangat diperlukan karena bahasa ini adalah bahasa ke-dua (second language) dan sangat jarang digunakan untuk berkomunikasi dalam keseharian. Dan juga, Bahasa inggris memiliki beberapa skill untuk dipelajari seperti listening, speaking, reading, dan writing sehingga diperlukan waktu yang tidak cepat dalam menguasinya. Kemampuan dalam bahasa inggris dipengaruhi oleh beberapa faktor yaitu motivasi (motivation), bakat (aptitude), dan kesempatan (opportunity).

Motivasi adalah sebuah faktor yang harus ada pada diri siswa dalam melaksanakan pembelajaran. Keberhasilan siswa dalam pembelajaran tergantung pada motivasinya karena motivasi mengarahkan mereka pada tujuan atau hasil yang diinginkan. Motivasi belajar yang dimiliki siswa dalam setiap kegiatan pembelajaran sangat berperan untuk meningkatkan prestasi belajar siswa dalam mata pelajaran tertentu, Nashar dalam ( Hamdu \& Agustina, 2011). ${ }^{3}$ Oleh karena itu, motivasi menjadi kunci untuk menggapai kesuksesan di masa yang akan datang.

Untuk mencapai keberhasilan akademik, motivasi siswa menjadi bagian yang sangat dibutuhkan dan tentunya akan memiliki pengaruh positif serta akan memberi kemudahan dalam siswa mencapai keberhasilan dalam pembelajaran. Motivasi juga memiliki peranan yang sangat penting untuk mempengaruhi kekuatan dalam aktifitas pembelajaran siswa. (Alizadeh, 2016) menyatakan bahwa "motivation gives the reasons for people's actions, desires, and needs". ${ }^{4}$ Menurutnya motivasi adalah alasan untuk seseorang melakukan sesuatu berdasarkan keinginan dan kebutuhannya.

Motivasi intrinsik adalah suatu bentuk keinginan untuk belajar yang sepenuhnya berasal dari dalam diri seseorang tersebut, sedangkan motivasi ekstrinsik memiliki makna yang kontradiksi dari motivasi intrinsik yaitu motivasi yang dimiliki

3 Hamdu, Ghullam; Agustina, Lisa, Pengaruh Motivasi Belajar Siswa Terhadap Pestasi Belajar IPA, Jurnal Penelitian Pendidikan, 2011, h.91

${ }^{4}$ Alizadeh, Mitra, The Impact of Motivation on English Language Learning, (International Journal of Research in English Education, 2016) h. 12 
oleh seseorang untuk belajar dikarenakan adanya faktor dari luar. Perilaku yang diprakarsai untuk menghindari hukuman juga dimotivasi secara ekstrinsik, meskipun banyak keuntungan intrinsik dapat dihasilkan dari mereka yang memandang penghindaran hukuman sebagai tantangan yang dapat membuat rasa kecakapan dan penentuan nasib mereka sendiri.

Hal ini senada dengan apa yang disampaikan (Littlewood, 2005) bahwa Motivasi adalah kekuatan penting yang menentukan apakah seorang pelajar memulai suatu tugas, berapa banyak energi yang dia curahkan untuk itu, dan berapa lama dia bertahan. ${ }^{5}$ Ini adalah fenomena yang kompleks dan mencakup banyak komponen; dorongan individu, kebutuhan untuk berprestasi dan sukses, rasa ingin tahu, keinginan untuk stimulasi dan pengalaman baru, dan sebagainya.

Fakta di Ma Attarbiyah Addiniyah Gersik Kediri Lombok Barat bahwa motivasi belajar siswa rendah. Hal tersebut disebabkan karena proses pembelajaran masih berpusat pada guru, dan penggunaan media pembelajaran kurang menarik, dimana guru masih menggunakan media pembelajaran yang merujuk pada buku paket. Hal tersebut sesuai dengan hasil wawancara bahwa dalam pembelajaran guru juga kurang optimal dalam penggunaan media pembelajaran, yang tentunya ini kurang tepat dalam penyampaian suatu konsep materi yang bersifag abstrak. Hal ini kurang efektif dan kurang sesuai dengan kondisi dan keinginan siswa sehingga siswa kurang antusias dalam mengikuti pembelajaran yang akhirnya menjadikan siswa kesulitan dalam memahami suatu materi yang disampaikan. Hal ini mengindikasikan bahwa motivasi siswa kurang selama proses pembelajaran berlangsung.

Selain itu, terlihat dari indikator kurangnya siswa mengerjakan tugas yang diberikan oleh guru, kurangnya literasi membaca siswa, kurangnya perhatian dalam belajar, dan kurangnya motivasi dalam berprestasi. Masalah lain ada sebagian siswa yang tidak mempunyai catatan pembelajaran sendiri karena siswa tersebut cukup puas dengan belajar dari fotokopi catatan temannya, ada sebagian siswa tidak mempersiapkan diri terhadap materi pembelajaran yang akan diajarkan guru sehingga terkesan sangat asing karena siswa belum pernah mempelajari sebelumnya,

5 Littlewood, William T, Foreign and Second Language Learning, (Newyork: Cambridge University Press, 2005) h. 14 
ada sebagian siswa yang tidak mengulang kembali materi pembelajaran yang telah diberikan guru sesegera mungkin dengan alasan masih banyak kesempatan di waktu lain untuk mengulang materi tersebut, ada sebagian siswa yang belajar bila menjelang ujian semesteran atau bila ada tugas dari guru yang memerlukan pemahaman. Permasalahan tersebut juga didukung dengan data hasil ulangan yang cukup rendah. Nilai yang diperoleh menunjukkan ada 10 dari 20 siswa yang nilainya di bawah KKM. Ini menunjukkan bahwa secara klasikal hanya 50 \% yang telah mencapai KKM dan $50 \%$ belum mencapai KKM yang telah ditetapkan.

Permasalahan yang terjadi yaitu rendahnya nilai siswa dipengaruhi oleh beberapa faktor diantaranya pembelajaran ini dianggap sulit, membingungkan, membosankan, dan kurang menarik. Masih rendahnya hasil belajar dikarenakan guru kurang memberi motivasi kepada siswa, serta jarangnya model pembelajaran yang bervariasi. Fakta tersebut sesuai dengan temuan Setiyowati (2013) bahwa mayoritas siswa kurang motivasi dalam belajar. Penggunaan metode yang kurang maksimal membuat pembelajaran tidak ada peningkatan bagi siswa. ${ }^{6}$ Senada dengan penelitian Setiawati (2018) bahwa rendahnya tingkat motivasi belajar siswa SMK Jawahirul Ulum Jabon Sidoarjo, hal tersebut berakibat terhadap rendahnya nilai hasil belajar siswa tersebut. ${ }^{7}$

Merujuk pada fakta di atas maka perlu dilakukan penelitian motivasi siswa dalam mempelajari bahasa inggris pada Ma Attarbiyah Addiniyah Gersik Kediri Lombok Barat ${ }^{8}$ karena Bahasa Inggris sebagai salah satu mata pelajaran sekolah dapat memberikan peran dan pengalaman bagi siswa. Hasil belajar bahasa Inggris dapat sangat dipengaruhi oleh motivasi belajar siswa. Baik motivasi intrinsik maupun ekstrinsik. Pembelajaran bahasa Inggris dilakukan dengan berbagai upaya, salah satunya dengan meningkatkan motivasi belajar. Dari segi belajar siswa, siswa akan berhasil jika memiliki kemauan untuk belajar dan keinginan atau motivasi untuk

${ }^{6}$ Setiyowati, Diah, Peningkatan Motivasi Belajar Bahasa Inggris Melalui Metode Total Physical Response (Tpr) Pada Siswa Kelas Ii Sdn Sidorejo Lor O7 Salatiga, skripsi, ( Jurusan Tarbiyah PGMI Sekolah Tinggi Agama Islam Negeri Salatiga, 2013) h. 6

7 Setiawati, FC, Peningkatan Motivasi Belajar Bahasa Inggris Melalui Penggunaan Aplikasi Android Siswa Di Smk Jawahirul Ulum Jabon Sidoarjo, skripsi, (Pascasarjana Universitas Islam Negeri Sunan Ampel Surabaya, 2017) h. VII

8 Observasi, di Ma Attarbiyah Addiniyah Gersik Kediri Lombok Barat, tanggal 11 Juli 2021 
belajar, karena ketika motivasi belajar meningkat maka siswa akan tergerak, menuju sikap, tingkatan dan perilaku siswa yang baru dalam belajar, dalam hal ini pembelajaran Bahasa Inggris.

\section{METODE PENELITIAN}

Penelitian tentang Motivasi Siswa Dalam Mempelajari Bahasa Inggris Pada Ma Attarbiyah Addiniyah Gersik Kediri Lombok Barat menggunakan metode pendekatan Deskriptif kuantitatif. Sampel dalam penelitian ini adalah siswa kelas XII Ma Attarbiyah Addiniyah Gersik Kediri Lombok Barat sebanyak 20 siswa dengan teknik cluster random sampling. Metode pengumpulan data menggunakan kuesioner berupa angket yang terdiri dari sepuluh pertanyaan tentang motivasi intrinsik dan sepuluh pertanyaan tentang motivasi ekstrinsik dengan menggunakan scale linkart dengan alternatif jawaban yaitu sangat setuju, setuju, tidak setuju, dan sangat tidak setuju. Mengenai penilaian, ada 1-4 poin, yaitu sangat setuju (SS) 4, setuju (S) 3, tidak setuju (TS) 2, sangat tidak setuju (STS) 1. Teknik analisis data menggunakan rumus persentase.

\section{HASIL DAN PEMBAHASAN}

Data hasil Motivasi Siswa Dalam Mempelajari Bahasa Inggris Pada Ma Attarbiyah Addiniyah Gersik Kediri Lombok Barat selengkapnya dapat dilihat pada Tabel berikut:

Tabel 1. Data hasil Motivasi Siswa Dalam Mempelajari Bahasa Inggris Pada Ma Attarbiyah Addiniyah Gersik Kediri Lombok Barat

\begin{tabular}{|c|c|c|}
\hline No & Kategori & Persentase (\%) \\
\hline 1 & Tinggi & 70 \\
\hline 2 & Sedang & 20 \\
\hline 3 & Rendah & 10 \\
\hline
\end{tabular}

Berdasarkan Tabel di atas, bahwa Motivasi Siswa Dalam Mempelajari Bahasa Inggris Pada Ma Attarbiyah Addiniyah Gersik Kediri Lombok Barat yaitu tinggi sebesar $70 \%$. Tingginya motivasi tersebut disebabkan oleh faktor ekstrinsik seperti lingkungan dan penghargaan dalam belajar serta kegiatan belajar yang menarik di dalam proses pembelajaran, sedangkan pada faktor instrinsik seperti hasrat dan 
keinginan siswa untuk berhasil. Akan tetapi jika dilihat dari ke dua faktor tersebut maka faktor instrinsik memiliki nilai yang lebih rendah dari pada faktor ekstrinsik. Hal tersebut disebabkan oleh siswa akan belajar bahasa inggris jika mendapat pujian maupun penghargaan baik dari rekan siswa, guru, maupun orang tua.

Sejalan dengan penelitian Mubarok (2019) bahwa motivasi ekstrinsik memegang peranan penting dalam keberhasilan pembelajaran bahasa inggris yaitu sebesar $3.04,{ }^{9}$ sehingga guru perlu mengoptimalkan keinginan siswa dalam belajar bahasa Inggris guna lebih bersemangat dan giat untuk mencapai keberhasilan dalam belajar bahasa Inggris.senada denga Fitriana (2018), bahwa motivasi belajar siswa tinggi, hal tersebut terlihat dari indikator siswa sudah dapat memberikan respond dalam berdialog sederhana dan menjawab pertanyaan secara lisan maupun verbal,walaupun sebahagian lagi masih perlu dibimbing terutama dalam penguasaan kosa kata. Lebih lanjut Dörnyei (2000); Dörnyei \& Ottó, (1998), bahwa motivasi merupakan konsep yang perlu diperhatikan dalam proses pembelajaran. 10

\section{KESIMPULAN}

Berdasarkan teori dan hasil pembahasan maka dapat disimpulkan bahwa motivasi memiliki peranan yang sangat penting sebagai penguat dalam diri siswa untuk meningkatkan keinginan dan kemauannya dalam mempelajari bahasa inggris dengan lebih baik dan lebih serius. Adapun hasil dari pembahasan sebelumnya, dapat diambil kesimpulan bahwasanya siswa MA Attarbiyah Addiniyah Gersik Kediri Lombok Barat cenderung memiliki motivasi yang datang dari ekstrinsik (luar) dibandingkan dari intrinsik (dalam) dalam mempelajari Bahasa Inggris. Hal ini menandakan bahwa siswa-siswa harus diarahkan secara khusus dan lebih serius agar lebih menyadari pentingnya mempelajari Bahasa Inggris bukan karena orang lain, akan tetapi karena dirinya sendiri yang membutuhkannya.

\section{SARAN}

9 Mubarok, TA, Motivasi Belajar Bahasa Inggris Pada Siswa Madrasah Aliyah Darul Muta'allimin Sugihwaras Patianrowo Nganjuk, (BRILIANT: Jurnal Riset dan Konseptual, 2019), h. 7

${ }^{10}$ Dörnyei, Z. and Kormos, J. The role of individual and social variables in oral task performance. Language Teaching Research, 2000, 4 (3), h. 275-300.

Dörnyei, Z. and Ottó, I Motivation in action: A process model of L2 motivation, 1998, h.275-300 
Bahasa inggris adalah bahasa asing yang sudah digunakan untuk berkomunikasi secara international menjadi bahasa yang sangat penting untuk dipelajari dan dikuasai, tentu hal ini membutuhkan tenaga dan usaha yang besar untuk mencapai keberhasilan dalam menguasainya. Oleh karena itu guru dan siswa diharapkan bisa berkerja sama untuk mencapai tujuan pembelajaran bahasa inggris yang diinginkan. Meningkatkan motivasi siswa dalam belajar juga perlu perhatian khusus agar siswa lebih menyadari apa yang menjadi kebutuhannya dan didasari oleh keinginannya sendiri.

\section{DAFTAR PUSTAKA}

Alizadeh, Mitra, The Impact of Motivation on English Language Learning, (International Journal of Research in English Education, 2016) h. 12

Dörnyei, Z. and Kormos, J. The role of individual and social variables in oral task performance. Language Teaching Research, 2000, 4 (3), h. 275-300.

Dörnyei, Z. and Ottó, I Motivation in action: A process model of L2 motivation, 1998, h.275-300 Working Papers in Applied Linguistics, Thames Valley University, London 4, 43-69.

Hamdu, Ghullam; Agustina, Lisa, Pengaruh Motivasi Belajar Siswa Terhadap Pestasi Belajar IPA, Jurnal Penelitian Pendidikan, 2011, h.91

Kristin, L, Leah, D, M, and Tenena, M, S.. Teaching Reading to English Language Learners. (New York: The Guilford Press, 2010) h. 56

Littlewood, William T, Foreign and Second Language Learning, (Newyork: Cambridge University Press, 2005) h. 12

Littlewood, William T, Foreign and Second Language Learning, (Newyork: Cambridge University Press, 2005) h. 14

Mubarok, TA, Motivasi Belajar Bahasa Inggris Pada Siswa Madrasah Aliyah Darul Muta'allimin Sugihwaras Patianrowo Nganjuk, (BRILIANT: Jurnal Riset dan Konseptual, 2019), h. 7

Observasi, di Ma Attarbiyah Addiniyah Gersik Kediri Lombok Barat, tanggal 11 Juli 2021

Setiyowati, Diah, Peningkatan Motivasi Belajar Bahasa Inggris Melalui Metode Total Physical Response (Tpr) Pada Siswa Kelas Ii Sdn Sidorejo Lor O7 Salatiga, skripsi, ( Jurusan Tarbiyah PGMI Sekolah Tinggi Agama Islam Negeri Salatiga, 2013) h. 6

Setiawati, FC, Peningkatan Motivasi Belajar Bahasa Inggris Melalui Penggunaan Aplikasi Android Siswa Di Smk Jawahirul Ulum Jabon Sidoarjo, skripsi, (Pascasarjana Universitas Islam Negeri Sunan Ampel Surabaya, 2017) h. VII 